Proc Soc Antiq Scot, 120 (1990), 45-53

\title{
Trial excavation of a terrace-edge enclosure at North Mains, Strathallan, Perthshire
}

\author{
G J Barclay* and Myra Tolan $\dagger$ \\ with contributions by Coralie Mills and J Barber
}

\begin{abstract}
A small part of the terrace-edge enclosure at North Mains was excavated to test the hypothesis that it was contemporary with one or other of the Neolithic/early Bronze-Age ceremonial monuments immediately to the north. Two cropmark ditches and an entrance through them were confirmed by excavation. The inner ditch was very steep-sided; postholes were found on the inner edge of both ditches. Possible postholes were also noted on the outer edge of the outer ditch. Traces of a number of structures were located in the interior, including what may be the slight wall-trench of a circular house. The results of radiocarbon dating may suggest that the ditch was dug in the second millennium bc, while at least one of the structures in the interior was in use in the late first millennium bc.
\end{abstract}

\section{INTRODUCTION}

In 1960, aerial reconnaissance by the Cambridge University Committee for Aerial Photography located a double-ditched enclosure on the edge of a terrace above the Machany Water in Strathearn, Perthshire (NGR NO 928 158): named Waulkmill in the National Monuments Record for Scotland. The next 20 years saw the discovery of the ring-ditches, henge and massive barrow at North Mains, immediately to the north, and, in 1978 and 1979, their excavation in advance of developments at Strathallan Airfield (Barclay 1983a). The location of the terrace-edge enclosure is illustrated in figure 1 of the North Mains report (Barclay 1983a, 124, no 5 on the map). Recent work on Neolithic defences in southern Britain and north-west Europe was presented at a conference in 1984 (Burgess et al 1988); in the light of these proceedings it was felt that a trial excavation to test the date and nature of the enclosure at North Mains would be worthwhile. Mercer (Discovery Excav Scot 1983, 19) had already conducted a trial excavation at Spott Dod in East Lothian, on an interrupted-ditch enclosure, to test a possible causewayed-camp interpretation; the site proved to be of Iron-Age date.

A two-week season of excavation, partly funded by a grant of $£ 250$ from the Society of Antiquaries of Scotland, was undertaken at North Mains in the summer of 1987; it had four aims:

1. to recover datable artefacts, and material for radiocarbon dating;

2. to find out if the apparent gap in the enclosure ditches was a constructed entrance;

3. to examine the nature of the ditches and any accompanying barrier and gate structure;

4. to sample, for traces of structures, an area chosen at random within the interior.

*Inspectorate of Ancient Monuments, Historic Buildings and Monuments, 20 Brandon Street, Edinburgh

$\dagger$ Department of Archaeology, University of Newcastle-upon-Tyne 


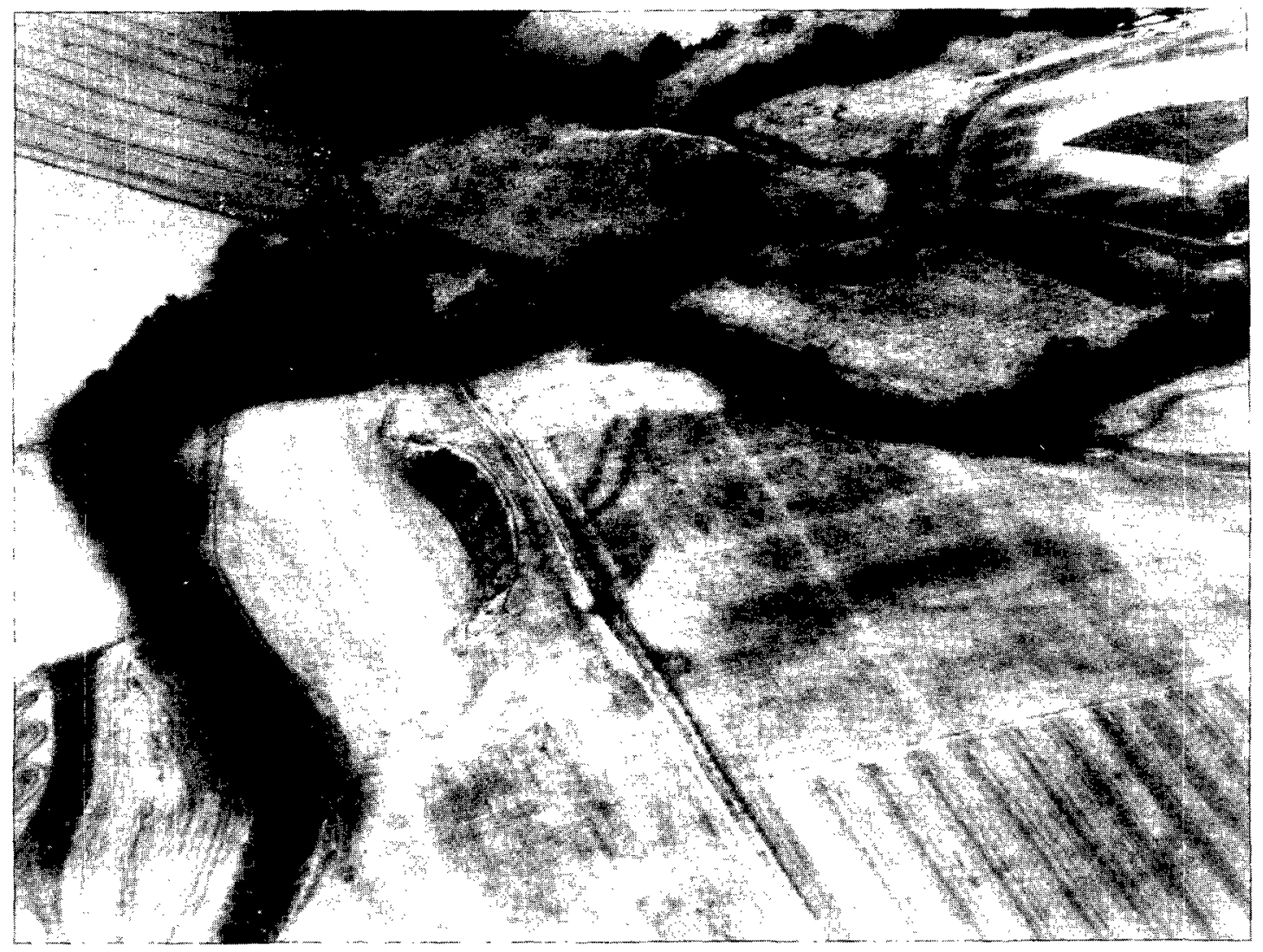

Illus 1 Aerial photograph of the North Mains enclosure: 1960 (CUCAP No AGO-92). At the point marked 'A' there are traces of a circular cropmark in grass, resembling a round house of the Bannockburn pattern. (Crown copyright/MOD; reproduced with the permission of the Controller of HMSO, the Cambridge University Committee for Aerial Photography and the Ministry of Defence (Crown Copyright))

\section{DESCRIPTION}

Two trenches were stripped of topsoil by machine and cleaned by hand. Area 1 (illus 3 ) was setout over the position of the apparent entrance (located on the ground by fluxgate gradiometer survey); area 2 was set out to the east on the same orientation (illus 5).

\section{AREA 1}

The main features located within the trench were the two ditches. Clear ditch-butts were found. Because of limited time and resources a section could be cut only through the inner ditch. The whole butt was excavated to a depth of $1 \mathrm{~m}$; it could be bottomed only in a narrow section.

\section{Inner ditch}

The ditch was over $2 \mathrm{~m}$ deep and $4 \mathrm{~m}$ across. It was very steep-sided and would have formed a very considerable barrier. On its inner edge, apparently cut by erosion of the lip of the ditch, was a substantial feature (1015), which may be interpreted as a posthole (illus 4i). As far as could be told, 


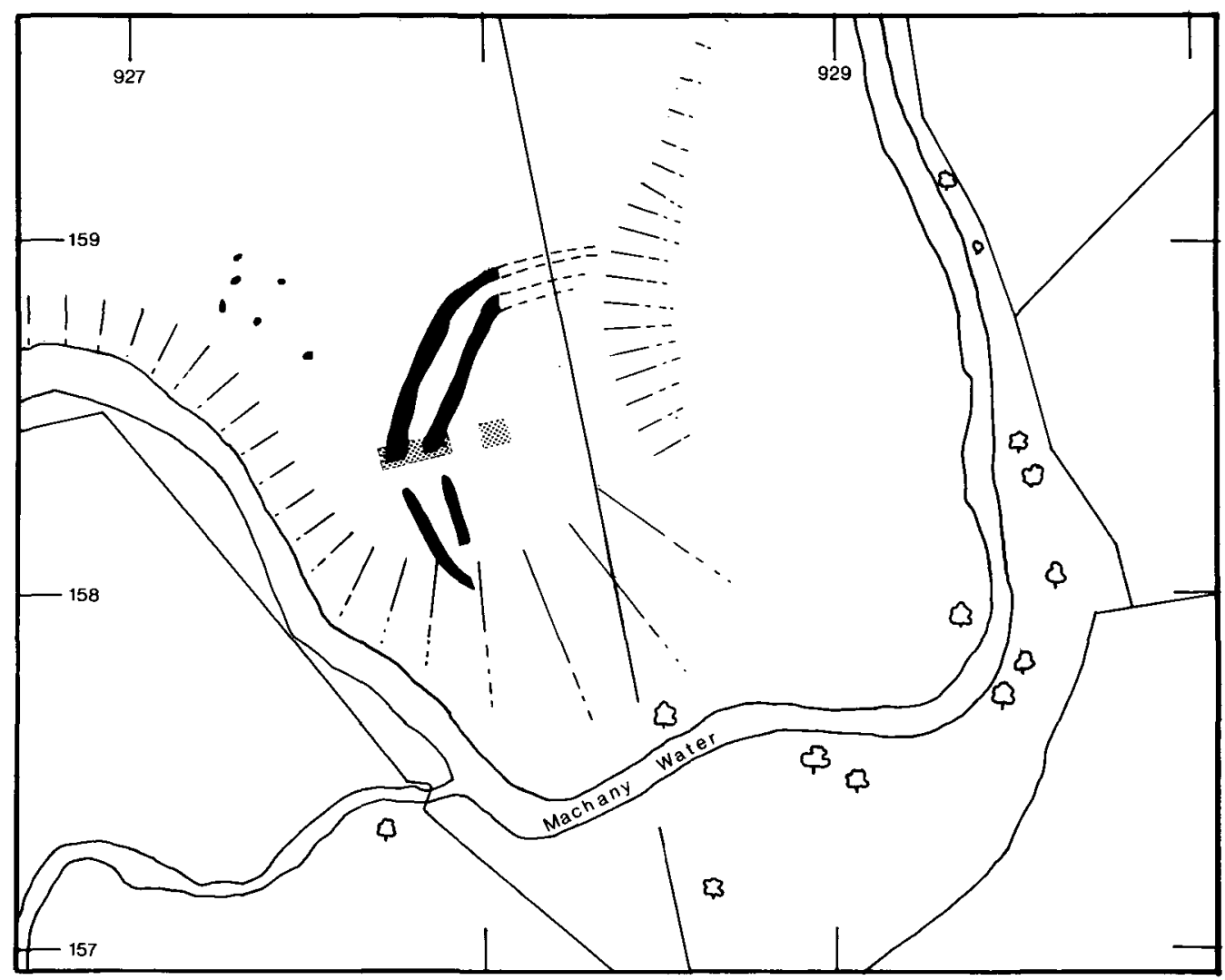

Illus 2 Plan of the visible cropmarks of the enclosure; the position of the excavation trenches is shown as a tone, Area 1 to the west, Area 2 to the east. Grid North lies at the top of the drawing

the ditch had filled naturally; however, towards the butt the quantity of large stone in the lower fills increased, as did the quantity of charcoal. Unfortunately the charcoal was in small flecks and in the event the sample recovered was not suitable for radiocarbon dating. In the topmost fill of the ditch an unusual feature was found: a roughly square platform of flattish stones measuring $1.9 \mathrm{~m}$ by $1.4 \mathrm{~m}$, tilted slightly, conforming to the slope of the ditch fill (illus 4ii). No artefacts were found associated with it, apart from pieces and flecks of charcoal on its surface; a radiocarbon date of $1300 \pm 80 \mathrm{bc}$ (GU2682) was obtained. The function of the platform was not clear; there was no evidence of intense burning.

\section{Outer ditch}

Although the ditch butt was not excavated, cleaning of the edges of the ditch to allow planning revealed a number of possible postholes. Of these, four proved on excavation to be real features $(1009,1013,1016$ \& 1017; illus 3 \& 6).

AREA 2

The trench measured c $7.5 \mathrm{~m}$ by $6.5 \mathrm{~m}$. Within it 15 separate features were located; many could be identified as certain or possible postholes (illus 5 \& 6). In 1005 a clearly defined post burnt in situ 


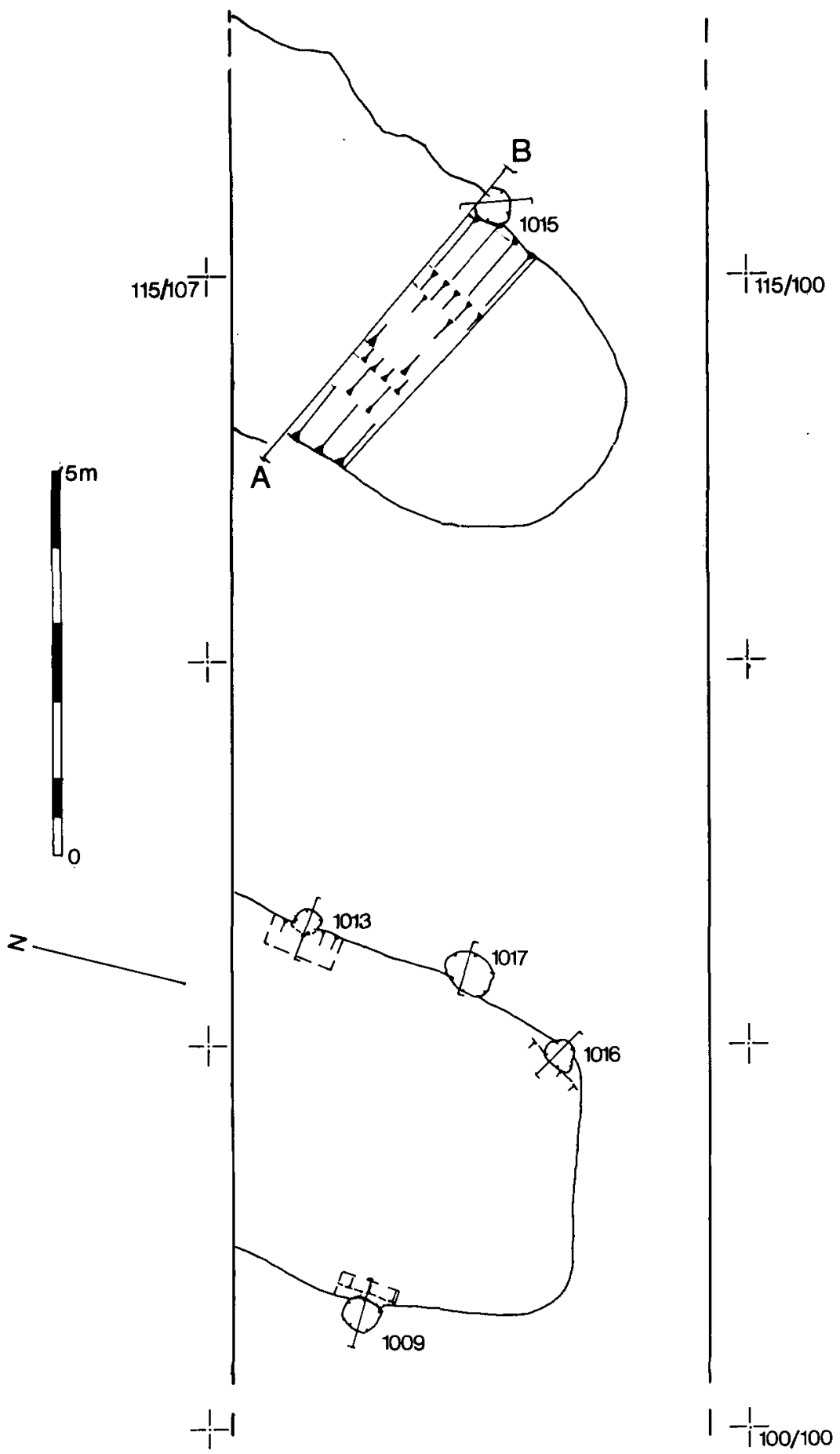

ILlus 3 Plan of Area 1, the outer ditch at the bottom, the inner ditch at the top 


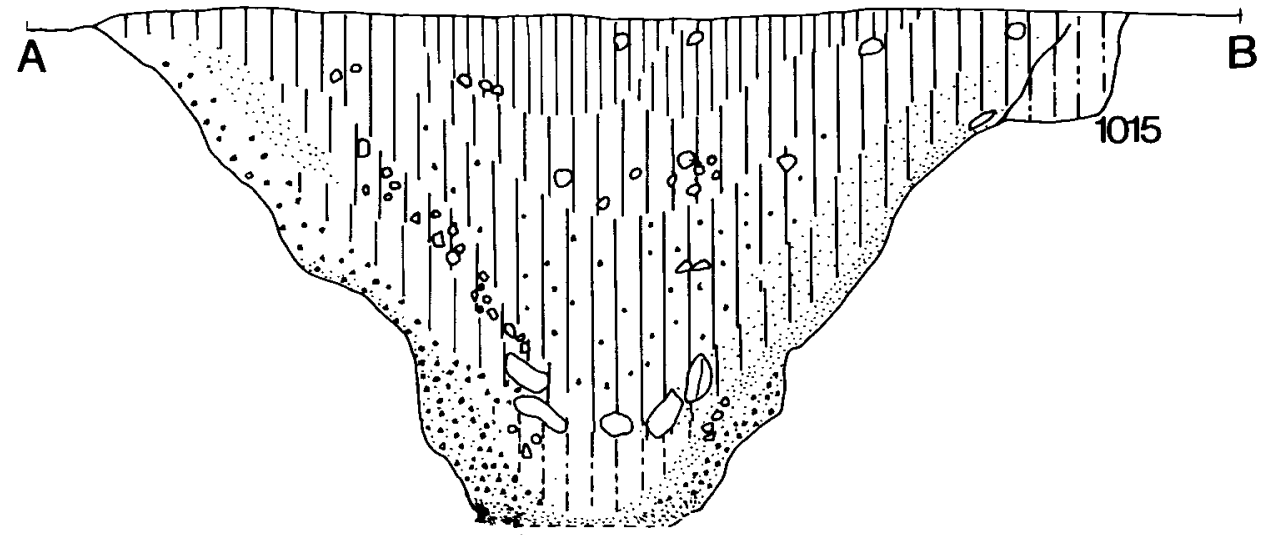

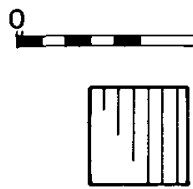

a

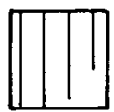

b

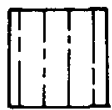

C

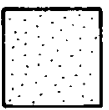

d

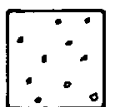

e

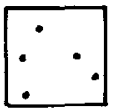

f

ILlus 4 Section of the inner ditch. The conventions are as follows: $a$, dark loam; $b$, medium loam; $c$, silt loam; $d$, sand; e, gravel; f, charcoal flecking. These conventions are used throughout the report

was noted; a radiocarbon date of $250 \pm 50 \mathrm{bc}$ (GU-2681) was obtained from the sample. In the southeast corner part of what seemed to be a large depression filled with dark loam was noted (1019); because the feature as it appeared in the excavated area seemed likely to be part of a greater whole, none of it was excavated. At the east edge a long curved linear feature was noted (1018: illus 5); on excavation it was found to be only $50 \mathrm{~mm}$ deep but clearly defined.

\section{INTERPRETATION AND DISCUSSION}

The enclosure at North Mains seems, by virtue of its substantial ditches and its situation, to have very much a defensive character. The features interpreted as postholes along the inner edges of the ditches seem likely to be the last remnants of palisades or fences associated with the ditches. On the outer ditch it may be suggested that a substantial fence was erected not only along the inner edge but possibly also the outer edge; a person attempting to enter the enclosure without using the more normal facilities might thus, on climbing the outer fence, be confronted by a fall of perhaps $4 \mathrm{~m}$ or more, and a near vertical climb of the same height again on the inner side. The great quantity of tumbled stone found in the butt of the inner ditch may indicate the presence of stone structures around the entrance through the ditches. It is not clear whether or not the posts along the edges of the ditches fronted dump ramparts formed from the gravel dug from the ditches or were the uprights of free-standing fences.

Parallels for a number of features found at North Mains can be found at Bannockburn in Central Region (Discovery Excav Scot 1982, 18; 1985, 8). The defensive ditches on the promontory fort there were dug through sand, an even more unsuitable material for rampart-building than the gravel at North Mains, and to the rear of the ditches were palisades. At the northern edge of the interior of the Bannockburn fort an arc of a slight wall-line of a circular house measuring some $14 \mathrm{~m}$ in 


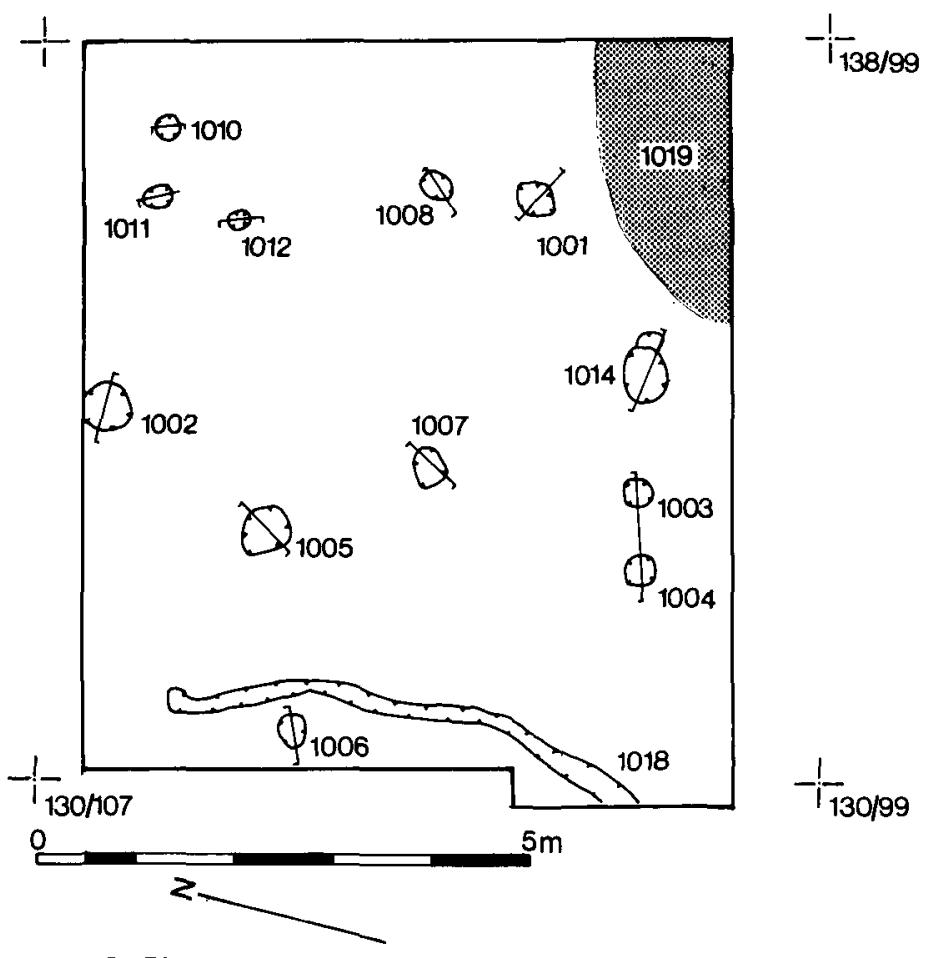

ILLUS 5 Plan of Area 2

diameter was found, similar to those located in Area 2 at North Mains and within the palisaded enclosure at Myrehead (Barclay 1983b).

At most the enclosure could have measured some $100 \mathrm{~m}$ by $60 \mathrm{~m}$ internally. For this limited area very substantial defences had been erected.

At the time of excavation it seemed likely that the complete lack of artefacts and the presence of at least one house structure probably of late Bronze-Age or Iron-Age type indicated that the enclosure was not Neolithic in date. We are most grateful to Historic Buildings and Monuments for offering to fund two radiocarbon samples from North Mains to assist with the interpretation of the possibly-related Bannockburn promontory fort.

The radiocarbon dates suggest that one of the structures in the interior was built using wood which had grown in the second half of the first millennium bc and that wood which had grown in the later part of the second millennium bc was burned in or near the filled-in inner ditch, possibly associated with the stone platform.

It was expected when the samples were submitted that the two radiocarbon dates would not be significantly different. We must attempt to explain the divergence. First, the problems of using limited numbers of radiocarbon dates must be acknowledged; neither date can be taken as absolutely reliable.

We are grateful to John Barber for contributing the following comment:

'The two radiocarbon dates are clearly significantly different from each other. Taphonomically, the later date seems more secure and we can be reasonably confident that it dates from a post which burnt in situ. The context from which the earlier date is derived is less secure. The charcoal could, for example, have weathered out of the eroding ditch side and come to rest on the platform. However, it is clear from the excavation account that this is extremely improbable. The survival of the postholes on the inner edge of the ditch suggests that the edges cannot have eroded back very far, if at all. 

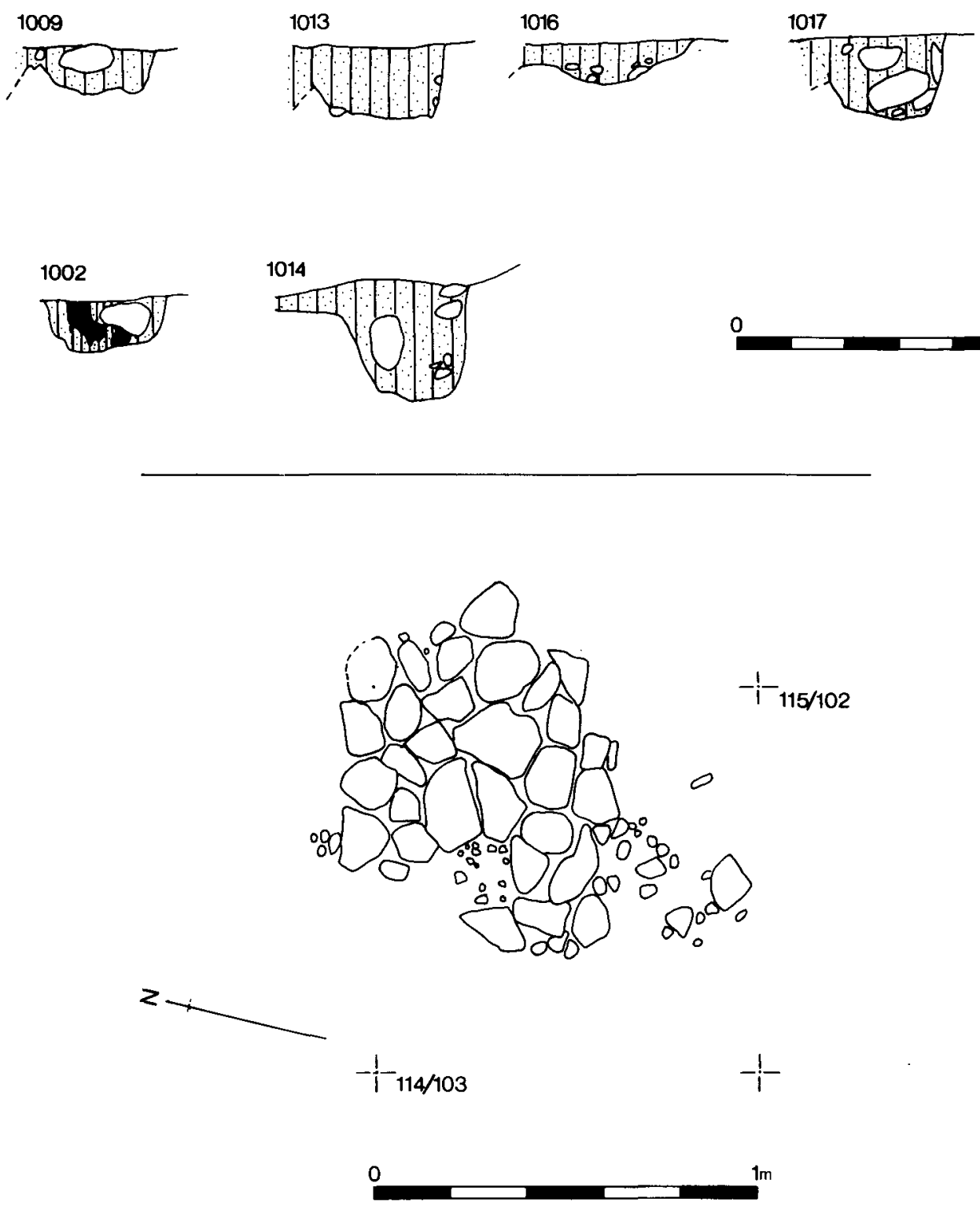

ILlus 6 i, Sections of features excavated in Areas 1 and 2; ii, Plan of paved area in upper ditch fills

The charcoal could be derived from sub-fossil (or 'bog') oak, used on a site which was exclusively Iron-Age in date. Dr Mills noted that only four fragments from this sample were identifiable and that all four were oak. She did not detect any insilting of the pore spaces, as one would expect in bog oak, nor any signs of mineralization. While this does not rule out the possibility, it indicates that there are no grounds for suggesting that the early date is caused by the use of subfossil materials on an Iron-Age site. It should be noted that the longevity of oak is not such as to account for differences in date of the order noted. A very few and very exceptional oaks have been known to survive for up to 400 to 500 years but the vast bulk of oaks do not exceed 200 to 300 years in age.' 
It may be suggested therefore that the original hypothesis has been proven; that is, the enclosure is of a date similar to some of the later activity on the henge or barrow. If it is accepted that the charcoal deposited on the surface of the stone platform built in the upper part of the ditch fills more or less accurately dates the use of the platform, then the ditch must have been dug earlier in the mid second millennium bc. The radiocarbon date is earlier than those for the phase IV burials excavated just to the north of the North Mains henge: $905 \pm 85 \mathrm{bc}$ (GU-1350); 1085 $\pm 70 \mathrm{bc}$ (GU-1351); $895 \pm 60$ bc (GU-1437) (Barclay 1983a, 143).

It can be suggested that the Iron-Age settlement phase dated to the later first millennium had been erected within the low banks of an earlier (later Bronze Age) enclosure, or coincidentally on a site where no significant earlier trace was visible; the possibility of continuous occupation from the later Bronze Age into the Iron Age must be considered.

The excavation at Kinloch Farm, Fife (Barber 1982) produced evidence of occupation in the $\mathrm{mid} /$ late Neolithic and perhaps in the late Neolithic/earlier Bronze Age, apparently associated with a roughly circular enclosure c $30 \mathrm{~m}$ in diameter within a double ditch. Mr Barber commented at that time:

'This group of features, on the basis of the aerial photographs available before excavation, seemed to represent a simple, probably single-period site for which comparanda, based on gross morphology, could be adduced which might indicate an Iron-Age date.'

It can be suggested, though with less satisfactory evidence than at Kinloch, that the origins of the North Mains enclosure may lie in the Bronze Age. The North Mains enclosure is a very different form of settlement from unenclosed types seen as characteristic of the later Bronze Age (eg Jobey 1980; Barclay 1983b). Further excavation in the class of undifferentiated enclosures so common in air photograph catalogues may reveal a greater variety of settlement types for this period than we would at present recognize.

\section{APPENDIX 1}

IDENTIFICATION OF CHARCOAL FROM NORTH MAINS

Coralie Mills

The charcoal samples from North Mains were forwarded for species identification, in advance of submission for radiocarbon dating. Identifications were made by reference to Schweingruber (1978), using a low power binocular microscope at magnifications of up to 90 times.

\section{Sample 1}

This sample has been interpreted as being from a post, burnt in situ (F 1002). The sample has fragmented into flat sheets of charcoal, but its appearance suggests that it could once have been a single lump of wood. Five fragments were identified, all as Quercus sp (oak). The longest sequence of rings seen was eight, but since neither the central ring or outer ring were present, the post must have been cut from an older tree.

The sample weighed c $90 \mathrm{~g}$, including some mineral material. There was some penetration by fine modern roots.

\section{Sample 2}

This small sample contained only four fragments of charcoal which were large enough for identification. All four were Quercus sp (oak). The longest sequence of annual rings seen was 20 , but the central rings were not present.

The total sample weight was c $11 \mathrm{~g}$, including some mineral matter. 


\section{Sample 3}

This sample was very small and comprised tiny pieces of charcoal. The size of the fragments meant that only tentative identifications could be made. Two fragments were identified as cf Salix sp (willow) and three as cf Pomoideae (group includes apple, pear, hawthorn and mountain ash). The total sample weighed only $1.5 \mathrm{~g}$, and much of this was mineral matter.

\section{APPENDIX 2}

\section{RADIOCARBON DATES}

Three samples of charcoal were submitted to the Scottish Universities Research and Reactor Centre.

\section{Sample 1}

(GU-2681) $2200 \pm 50 \mathrm{bp}$. This sample was from F 1002 and appeared to be a post burnt in situ.

\section{Sample 2}

(GU-2682) $3250 \pm 80 \mathrm{bp}$. This sample was from the surface of the paved area constructed in the upper fill of the inner ditch.

\section{ARCHIVE}

The drawings, site records, photographs and ephemera have been lodged with the National Monuments Record for Scotland.

\section{ACKNOWLEDGEMENTS}

The excavation could not have taken place without the kind permission of the owner of the site, Sir William Roberts of Strathallan Castle, and a grant from the Society of Antiquaries of Scotland. We are happy to record our indebtedness to both.

We are both very grateful to the local people who came frequently to help us excavate: Bob Buchan, Gil Reid and Bert and Terry Lanning; without them far less could have been achieved. The hospitality of Alison Reid, then of Perth Museum must also be recorded with thanks.

Tools and equipment were loaned to the project by Historic Buildings and Monuments and the Archaeology Department of Edinburgh University; we are grateful to both institutions. GJB wishes to acknowledge particularly the assistance of HBM in his research.

We are grateful to Gordon Maxwell and I Parker of RCAMS for plotting the cropmarks for us.

\section{REFERENCES}

Barber, J 1982 'The investigation of some plough-truncated features at Kinloch Farm, Collessie in Fife', Proc Soc Antiq Scot, 112 (1982), 524-33.

Barclay, G J 1983a 'Sites of the third millennium bc to the first millennium ad at North Mains, Strathallan, Perthshire', Proc Soc Antiq Scot, 113 (1983), 122-281.

Barclay, G J 1983b 'The excavation of a settlement of the later Bronze Age and Iron Age at Myrehead, Falkirk District', Glasgow Archaeol J, 10 (1983), 41-71.

Burgess, C, Topping, P, Mordant, C \& Maddison, Margaret 1988 Enclosures and Defences in the Neolithic of Western Europe. Oxford. (=Brit Archaeol Rep Int Ser, 403.)

Jobey, G 1980 'Green Knowe unenclosed platform settlement and Harehope Cairn, Peeblesshire', Proc Scot Antiq Scot, 110 (1978-80), 72-113.

Schweingruber, F H 1978 Microscopic Wood Anatomy. Fluck-Wirth; Teufen, Switzerland.

This paper is published with aid of a grant from the Historic Buildings and Monuments Directorate (SDD) 